\title{
NUTRITIONAL CARE IN PEPTIC ULCER
}

\author{
Cuidados nutricionais na úlcera péptica
}

\author{
Nathália Dalcin VOMERO, Elisângela COLPO
}

From the Curso de Nutrição do Centro Universitário Franciscano - UNIFRA (Nutrition Course of Franciscan University (enter), Santa Maria, RS, Brazil.

HEADINGS - Nutrition. Dietotherapy. Helicobacter pylori. Nutritional therapy, treatment.
ABSTRACT - Introduction: Peptic ulcer is a lesion of the mucosal lining of the upper gastrointestinal tract characterized by an imbalance between aggressive and protective factors of the mucosa, having $H$. pylori as the main etiologic factor. Dietotherapy is important in the prevention and treatment of this disease. Aim: To update nutritional therapy in adults' peptic ulcer. Methods: Exploratory review without restrictions with primary sources indexed in Scielo, PubMed, Medline, ISI, and Scopus databases. Results: Dietotherapy, as well as caloric distribution, should be adjusted to the patient's needs aiming to normalize the nutritional status and promote healing. Recommended nutrients can be different in the acute phase and in the recovery phase, and there is a greater need of protein and some micronutrients, such as vitamin A, zinc, selenium, and vitamin $\mathrm{C}$ in the recovery phase. In addition, some studies have shown that vitamin $\mathrm{C}$ has a beneficial effect in eradication of $H$. pylori. Fibers and probiotics also play a important role in the treatment of peptic ulcer, because they reduce the side effects of antibiotics and help reduce treatment time. Conclusion: A balanced diet is vital in the treatment of peptic ulcer, once food can prevent, treat or even alleviate the symptoms involving this pathology. However, there are few papers that innovate dietotherapy; so additional studies addressing more specifically the dietotherapy for treatment of peptic ulcer are necessary.

\section{Correspondence: \\ Elisângela Colpo \\ E-mail: elicolpo@yahoo.com.br \\ Financial source: none \\ Conflicts of interest: none}

Received for publication: 13/02/2014 Accepted for publication: 23/05/2014

DESCRTORES - Nutrição. Dietoterapia. Helicobacter pylori. Terapia nutricional, alimentação. Tratamento.
RESUMO - Introdução: A úlcera péptica é uma lesão que ocorre na mucosa do trato gastrointestinal, sendo caracterizada por um desequilíbrio entre fatores agressores e protetores da mucosa gástrica, tendo como principal fator etiológico o $\mathrm{H}$. pylori. A dietoterapia é fundamental na prevenção e tratamento dessa patologia. Objetivo: Rever a terapia nutricional na úlcera péptica em adultos. Métodos: A metodologia utilizada foi um estudo exploratório de revisão do conhecimento disponível na literatura científica. Resultados: A dietoterapia bem como a distribuição calórica deve ser ajustada as necessidades do paciente com objetivo de normalizar o estado nutricional e promover a cicatrização. As recomendações de nutrientes podem ser diferenciadas nas fases aguda e de recuperação, havendo uma maior necessidade proteica e de alguns micronutrientes como vitamina $A$, zinco, selênio e vitamina $C$ na fase de recuperação. Além disso, alguns estudos evidenciam que a vitamina $C$ tem efeito benéfico na erradicação do $H$. pylori. As fibras e probióticos também possuem um importante papel no tratamento da úlcera péptica, reduzindo os efeitos colaterais dos antibióticos e auxiliando na redução do tempo de tratamento. Conclusão: Percebe-se que poucos são os trabalhos que evidenciam a terapia nutricional da úlcera e não há consenso sobre o tema. Com isso, mais estudos são necessários para abordar com maior especificidade o tratamento dietoterápico da úlcera péptica. Dieta equilibrada é fundamental no tratamento da úlcera péptica, uma vez que o alimento pode prevenir, tratar ou mesmo aliviar os sintomas que envolvem esta doença. No entanto, existem poucos trabalhos que inovam dietoterapia; assim, são necessários estudos adicionais abordando mais especificamente a dietoterapia para o tratamento de úlcera péptica.

INTRODUCTION

$\mathrm{P}$ eptic ulcer is a disease of chronic development, characterized by an imbalance between the factors that damages the mucosa and those for its protection, resulting in a lesion of the lining of the upper digestive tract ${ }^{22}$. It has been one of the most prevalent diseases in the world, and some of its complications have been the major causes of morbidity and mortality ${ }^{34}$. The prevalence differs in the world population between the duodenal and gastric ulcers, and the mean age of people with the disease is between 30 and 60 years, but it can happen in any age. Racial difference has also been observed, and in Africa duodenal ulcers are found to be rare in black people, but in the United States the incidence is the same for blacks and whites; regarding gender, there is predominance of ulcers in males ${ }^{16}$.

Peptic ulcer has a multifactor etiology. Environmental elements such as alcohol and nicotine can inhibit or reduce secretion of mucus and bicarbonate, increasing acid secretion. Genetic factors can influence, and children of parents with duodenal ulcer are three times more likely to have ulcer than the population ${ }^{14}$. In the past decades, the identification of Helicobacter pylori and ulcers associated with the chronic use of antiinflammatory drugs contributed to a better understanding of the events associated to the genesis of peptic ulcers ${ }^{36}$.

Nutrition and its recommendations define aspects of a healthy diet, and the 
need to establish nutritional benchmarks is long recognized as a way to promote health and prevent and treat diseases. Accordingly, dietotherapy has played a key role in the prevention and treatment of Peptic ulcer, with the main purpose of recovering and protecting the gastrointestinal lining, improving digestion, relieving pain, and contributing to a satisfactory nutritional status ${ }^{29}$.

Peptic ulcer is a disease known since antiquity, but there are few studies innovating dietotherapy as treatment for this disease. For this reason, the objective of this study was to review nutritional therapy of peptic ulcers in adults.

METHOD

Review of the knowledge available in the scientific literature about nutritional therapy of peptic ulcer, without restrictions of date, based on Scielo, PubMed, Medline, ISI, and Scopus databases. Was also included data from national and international health committees. For the search in databases, were used the following descriptors: dietotherapy, nutrition, peptic ulcer, Helicobacter pylori, pepper, iron, protein, antioxidants, bioavailability of nutrients, food fibers, zinc, probiotics, vitamin $\mathrm{C}$ and $\mathrm{E}$.

\section{RESULTS}

\section{Physiopathology and etiology}

Peptic ulcer is characterized by a solution of continuity the upper digestive tract mucosa exposed to chloride peptic secretion. It often occurs in the duodenum (5-10\% of the population), stomach or esophagus ${ }^{36}$. It is a chronic disease, with activation and remission periods and its pathogenesis is characterized by the imbalance between the factors that damages the mucosa (chloride acid, pepsin, and ulcerogenic drugs) and those that protect it (mucosal barrier, prostaglandins, and mucosal secretion $)^{18}$. Clinical manifestations are characterized by epigastric discomfort, burning or severe and continuous pain, which tends to be worse at night. Pain usually happens one to three hours after eating, and may be followed by nauseas, vomiting, discomfort in the gastrointestinal tract, flatulence, and significant loss of body weight ${ }^{22}$.

Important factors in the etiopathogenesis are tobacco, alcohol, and Helicobacter pylori, which is able to move in high viscosity medium, adhering to the mucosa epithelium, where it remains protected ${ }^{18}$. Diagnosis of this infection may be achieved through various tests, each with a sensitivity and specificity above $80 \%$. The golden standard test is the upper endoscopy, which allows the physician to collect material to check for the presence of $H$. pylori besides other therapeutic procedures $^{36}$.

\section{Nutritional assessment on peptic ulcer}

It aims to identify possible nutritional alterations and determine proper intervention to ensure the individuals' health. Malnutrition in this case may occur especially when there is stenosis, which prevents normal ingestion of foods ${ }^{18}$.

For nutritional assessment, some important indicators are used in this process, such as the anthropometric, biochemical, and clinical evaluations. The anthropometric assessment consists of weight and height measurements that may be used in conjunction in the assessment of the nutritional status by means of BMI (Body Mass Index), but this method does not distinguishes losses of fat or lean mass. In addition, weight may be concealed by hyper-hydration or de-hydration, thus not resulting in an accurate determination of the nutritional status in these specific cases ${ }^{18}$.

Total body bioelectrical impedance is a method used to measure the body mass, liquid volume, and body fat, being recognized by the Brazilian Ministry of Health and the Food and a Food and Drug Administration as a valuable technique for this purpose ${ }^{14}$. Indirect calorimetry is a non-invasive method to determine the nutritional needs and the utilization rate of energy substrates from oxygen consumption and carbon dioxide production obtained by analysis of the inhaled and exhaled air by the lungs ${ }^{8}$.

The upper arm muscle circumference is a measure to assess somatic protein compartment, and the corrected muscle arm area is a more accurate method because it reflects the actual magnitude of muscle tissue alterations appropriately. The triceps skinfold is the most used skinfold because it is the triceps region that best represents the adipose subcutaneous layer ${ }^{28}$.

Biochemical tests are able to diagnose possible deficiencies still in the subclinical phase and includes serum albumin, which plays a key role in the nutritional assessment - serum pre-albumin a sensitive indicator of protein deficiency -, having several advantages to help determine the nutritional status and intervention needs ${ }^{18}$. Complete blood test is often used in this case, because it involves counts of white and red blood cells, reticulocytes and platelet, hematological indices, thus allows to monitor blood alterations and a progress analysis of the disease ${ }^{18}$. Nitrogen balance is a noninvasive and accessible technique consisting of the difference between taken-in oxygen and excreted oxygen used to assess metabolic stress, and is a good parameter to assess protein intake and protein degradation ${ }^{17}$.

\section{Characteristics of nutritional therapy}

The objective of peptic ulcer dietotherapy is to prevent hyper secretion of peptic chloride in order to reduce the sore and pain in the gastric and duodenal mucosa. In addition, nutritional therapy aims to promote healing, based on a complex sequence of events going from the initial trauma to the repair of the damaged tissue. Investigation of nutritional deficiencies is essential in the preparation of an appropriate recovery diet. In the early $20^{\text {th }}$ century, Sippy proposed a diet based on milk and milk cream, combined with antacids, for treatment of gastrointestinal ulcer, based on the principle that milk would provide gastric alkalinization and relieve pain. Today milk is not recommended due to the buffering effect and the significant gastric acid secretion effect of milk ${ }^{29}$.

According to Marrota and Floch ${ }^{18}$, calories distribution for patients with peptic ulcer should be normal, with values ranging from $50-60 \%$ of carbohydrates, $10-15 \%$ of proteins, and $25-30 \%$ of lipids, with total energy value sufficient to maintain or recover the nutritional status.

Reis $^{29}$ suggested that calories distribution should be adjusted according to the patient's needs to normalize the nutritional status, having as recommended macronutrients a protein intake of up to $1.2 \mathrm{~g} / \mathrm{kg} /$ weight/day in the acute stage ( $5^{\text {th }}$ to $8^{\text {th }}$ week) and up to $1.5 \mathrm{~g} / \mathrm{kg} /$ weight/day in the recovery stage. Carbohydrates should be adjusted to the patient's needs, without disaccharides concentration, so as to avoid fermentation, and lipids without concentration of saturated fats.

To accelerate the healing process, in addition to protein, there are specific micronutrients such as zinc, which is essential to maintain the immune system function, as a response to oxidative stress, and to heal wounds ${ }^{25}$. Selenium may reduce infection complications and improve healing ${ }^{10}$. In addition, vitamin A may be used as a supplement, but the research that supports this practice is of limited effectiveness, because very high dosages do not promote cure, and excessive intake may be toxic ${ }^{2}$. Nutritional recommendations for patients with peptic ulcer are described in Table 1. 
Despite the small number of references covering the required amounts of nutrients in the treatment of peptic ulcer, it can seen that the authors agree with the recommendations to improve healing, differing only when the patient is in the active or remission phase. Therefore, to help plan a more specific and safe action, it is important to investigate the individual's nutritional status and if the patient has any associated pathology.

TABLE 1 - Recommended daily diet for peptic ulcer

\begin{tabular}{|c|c|c|}
\hline Characteristics & \multicolumn{2}{c|}{$\begin{array}{c}\text { Recommendations } \\
\text { Sufficient to maintain or recover the } \\
\text { nutritional status }\end{array}$} \\
$\begin{array}{c}\text { Daily energy needs } \\
\text { (DEN) }\end{array}$ & $\begin{array}{c}20-25 \mathrm{Kcal} / \mathrm{Kg} \text { : weight loss } \\
25-30 \mathrm{Kcal} / \mathrm{Kg} \text { : maintenance } \\
30-35 \mathrm{Kcal} / \mathrm{Kg} \text { : weight gain }\end{array}$ \\
\hline & $\begin{array}{c}\text { Acute phase } \\
\text { Recovery phase }\end{array}$ \\
\hline Carbohydrate $(\%)^{29}$ & $50-60$ & $50-60$ \\
\hline Protein $(\mathrm{g} / \mathrm{Kg} / \text { weight })^{29}$ & 1.2 & 1.5 \\
\hline Lipid $(\%)^{18,29}$ & $25-30$ & $25-30$ \\
\hline Zinc $(\mathrm{mg})^{13}$ & 11 & 40 \\
\hline Selenium $(\mu \mathrm{g})^{20}$ & 55 & 400 \\
\hline Vitamin $\mathrm{A}(\mu \mathrm{g}) 1^{13}$ & 900 & 3000 \\
\hline Vitamin $\mathrm{C}(\mathrm{mg})^{13}$ & 75 & 500 \\
\hline Vitamin $\mathrm{B}_{12}(\mu \mathrm{g})^{13}$ & 2.4 & 2.4 \\
\hline Folic acid $(\mu \mathrm{g})^{13}$ & 400 & 400 \\
\hline Iron $(\mathrm{mg})^{13}$ & 45 & 45 \\
\hline Fibers $(\mathrm{g})^{13}$ & 20 to 30 & 20 to 30 \\
\hline Probiotics $(\mathrm{UFC} / \text { day })^{18}$ & $10^{9}$ to $10^{11}$ lactic acid & $10^{9}$ to $10^{11}$ lactic \\
bacteria & acid bacteria \\
\hline
\end{tabular}

Sources: ${ }^{18}$ Marrota; Flock (1993); ${ }^{29}$ Reis (2003); ${ }^{13}$ DRI'S (UL); ${ }^{13}$ DRI'S (RDA

\section{Use of food fibers in peptic ulcer treatment}

The physicochemical properties of fiber fractions produce different physiological effects in the organism. Soluble fibers, found in apple, oatmeal, and pear are responsible, for instance, for an increased viscosity in the intestinal content. Insoluble fibers (whole grains, granola, flaxseed) increase stool bulk, reduce transit time in the large intestine, and make fecal elimination easier and quicker. Fibers regulate the bowel function, which make them vital for the well being of healthy people and in the dietary treatment of many pathologies ${ }^{19}$.

Räihä et al. ${ }^{26}$ reported a large number of patients with peptic ulcer having diets poor in fibers and antioxidants. A diet rich in fibers for individuals with peptic ulcer is advisable (20 to $30 \mathrm{~g} /$ day, according to WHO - World Health Organization), because fibers act as buffers, reducing concentrations of bile acids in the stomach and the intestinal transit time, resulting in less abdominal bloating, thus decreasing discomfort and pain in the gastrointestinal tract ${ }^{18}$.

\section{Use of probiotics in peptic ulcer}

Probiotics are defined as a food supplement based on live microorganisms, which affect beneficially the human organism by providing a microbial balance ${ }^{33}$. There is a special interest in probiotics for treating infection by $\mathrm{H}$. pylori, because it plays a crucial role in the pathogenesis of chronic gastritis and peptic ulcer in adults ${ }^{9}$. Probiotics have therapeutic agents against $H$. pylori, which can be shown by clinical data that prove the efficacy of some probiotics in diverse gastrointestinal diseases and also due to the increasing resistance of pathogenic bacteria to antibiotics ${ }^{35}$.

One of the measures that may contribute to reduce the infection rate by $H$. pylori is dietary modulation with the addition of probiotics. However, probiotic organisms do not appear to eradicate $H$. pylori, but have the ability to reduce the bacterial load and infection in animals and humans ${ }^{32}$. Studies on humans indicate that probiotics improve slightly the elimination rate in treatment against $H$. pylori, being useful to decrease the bacterial load and likely improve dyspeptic symptoms ${ }^{37}$. Thus, an intake of $10^{9}$ to $10^{11} \mathrm{CFU} /$ day of lactic acid bacteria is recommended.

Among the clinical applications of probiotics, reduction of the side effects associated with antibiotics is the best indication documented. According to Cats et al. ${ }^{4}$, who conducted an intervention study, 14 patients infected with $H$. pylori receiving $L$. acidophilus $\left(10^{8} \mathrm{CFU}\right)$ for three weeks, it was capable of inhibiting the growth $\mathrm{H}$. pylori in $64 \%$ of the volunteers. Similarly, in a study by Wang et al. ${ }^{38}$ with 59 volunteers, they received Bifidobacterium animalis and $L$. acidophilus $\left(10^{10} \mathrm{CFU}\right)$ twice a day during six weeks, and concluded that regular intake of yogurt containing Bifidobacterium animalis and L. acidophilus can effectively suppress the infection caused by $H$. pylori in humans.

Use of antioxidants to eradicate Helicobacter pylori

Some authors show that the best treatment is the eradication of the bacteria ${ }^{18}$. Accordingly, some studies in humans ${ }^{40}$ used antioxidants to eradicate $H$. Pylori and observed that vitamin $C$ has important effects in the bacteria eradication in patients with peptic ulcer. But these studies showed that smaller doses of vitamin $C$ for a longer period of time had a better response when compared with higher doses. Thus, it is observed that patients with peptic ulcer by H. pylori can take up to $500 \mathrm{mg}$ /day of vitamin C for a period of three months, which does not exceed the recommended UL of $2000 \mathrm{mg}$, according to DRIs ${ }^{13}$.

Another antioxidant used to eradicate $H$. pylori is the capsaicin present in pepper and chilies. Studies on animals showed that capsaicin has effect in healing gastrointestinal lesions. Likewise, some researchers ${ }^{39}$ studied the effect of capsaicinoids in individuals with peptic ulcer by $H$. pylori or aspirin and showed that these substances are gastroprotective only in individuals with aspirin-induced lesions. It is worth noting that peppers may be associated with irritations in the gastric mucosa, and may not have a gastroprotective effect in some individuals with peptic ulcer.

Substances that can potentiate peptic ulcer symptoms According to César et al. ${ }^{5}$, damages caused by ulcer can be reverted, often after treatment of an infection caused $H$.

TABLE 2 - Allowed foods, foods that should be consumed with caution, and foods that must be avoided

\begin{tabular}{|c|c|c|c|}
\hline Food groups & Allowed & Use with caution & Prohibited \\
\hline Dairy & Milk, low-fat cheeses, yogurt, fermented milk & $\begin{array}{c}\text { Fatty cheeses (mascarpone, cream cheese, } \\
\text { gorgonzola) }\end{array}$ & - \\
\hline Oilseeds & Flaxseed, Brazilian nut, walnuts & - & - \\
\hline Oils and olive oils & Vegetable oils, olive oil & - & Fried foods \\
\hline Fruits & Apple, papaya, melon, banana & Orange, pineapple, acerola, passion fruit & Lemon \\
\hline Vegetables & $\begin{array}{l}\text { Leafy dark green vegetables, carrot, beet, green bean, } \\
\text { spinach, kale, radish, zucchini, leek }\end{array}$ & $\begin{array}{c}\text { Broccoli, cauliflower, cabbage, cucumber, } \\
\text { onion, red pepper }\end{array}$ & Spicy peppers (black pepper, chilies) \\
\hline Legumes & Bean soup, lentils, chickpeas, soybean & Beans & - \\
\hline Meats & Lean meat (beef, pork, chicken, fish) & Fatty meats, organ meats and sausages & - \\
\hline Sweets & - & Concentrated sweets & Chocolate \\
\hline Beverages & Natural juices & Citrus/acidic fruit juices & Coffee, black tea, fizzy/cola drinks \\
\hline Other foods & - & $\begin{array}{l}\text { Industrialized seasonings, spices and } \\
\text { condiments (Ketchup, mayonnaise, mustard) }\end{array}$ & Mustard grain \\
\hline
\end{tabular}


Pylori, by changing diet and lifestyle. Ferri-De-Barros et al. ${ }^{11}$ observed that alcohol consumption causes damages to the digestive tract with appearance of symptoms of ulcer and other alcohol-related diseases, such as esophagitis, chronic pancreatitis, gastritis, among others.

According to Reis ${ }^{29}$, smoking diminishes secretion of mucus and bicarbonate, raising the duodenal and gastric flow and increasing the risk of ulcers formation. Prospective and retrospective studies show higher mortality from peptic ulcer in smokers when compared to nonsmokers. Researches show that, among other tobacco constituents, nicotine accounts for most of the peptic ulcer development, because it has a harmful effect on the protective mucus of the gastric epithelium, altering bicarbonate ${ }^{30}$.

Coffee, even decaffeinated coffee, raises gastric acid production, resulting in mucosal irritations. The same goes for soft drinks, which, besides increasing acid production, are gaseous and cause gastric distension and is dyspepsiarelated ${ }^{18}$. However, it is important to take into account individual tolerances, with attention to the existence of misconceptions about foods and their actions in the body. Table 2 indicates foods that are prohibited and should be avoided by people with peptic ulcer.

\section{Antacids versus nutrients bioavailability}

Deficiency of vitamin $B_{12}$ is common in patients with peptic ulcer due to the prolonged use of antacids, making difficult the bioavailability of this vitamin. Vitamin $B_{12}$ can be synthetized by the intestinal microbiota in the colon, but is not absorbed. Deficiency of this vitamin causes impaired cell division and megaloblastic anemia. It is estimated that $80-90 \%$ of patients lacking vitamin $B_{12}$ develop neurological alterations, if not treated ${ }^{24}$. As a result, recommendation is for $2.4 \mu \mathrm{g} /$ day of this vitamin, which can be obtained from animal foods, such as milk, meat and eggs.

Absorption of folic acid can be impaired in subjects that make chronic use of aluminum-based antacids (Pepsamar ${ }^{\circledR}$, Gastran ${ }^{\circledR}$, Alca-Luftal $\AA$ ), because antacids make the $\mathrm{pH}$ of the jejunum more alkaline ${ }^{23}$. In these cases, intake of 400 $\mu \mathrm{g} /$ day of this vitamin is necessary, which can be supplied with ingestion of leguminous foods, such as lentils, and meats. It is important to emphasize that the reduction of the gastric acidity by antacids or antiulcers (Lanzol $\AA^{\text {, Prazol }}{ }^{\circledR}$, Omeoprazol $\left.{ }^{\circledR}\right)$ alters proteins digestion and affects good digestion of foods ${ }^{21}$.

Antacids can also diminish absorption of iron, causing iron-deficiency anemia. Gastrointestinal bleeding can be observed in gastroduodenal ulcer and infection by $H_{\text {. pylori }}{ }^{1}$ and may be associated with the development of anemia. Gastric bleeding is a major complication of peptic ulcer ${ }^{22}$.

Infection by $H$. pylori can also lead to an imbalance of body iron homeostasis due to the growing demand for iron by the same. Similarly to other kinds of bacteria, iron is essential for the growth of $H$. pylori $i^{1}$. To prevent or even treat iron deficiency, an intake of $45 \mathrm{mg}$ of iron daily is recommended, which can be supplied by the ingestion of meats, the main source of heme iron. It is estimated that 100 $\mathrm{g}$ of meat correspond to $1 \mathrm{~kg}$ of beans (non-heme iron). The concomitant consumption of fruit juice containing vitamin $C$ enhances the non-heme iron absorption from the diet ${ }^{1}$.

\footnotetext{
Alternative treatments without proven efficacy in peptic ulcer

The potential of plants as source of new drugs still offers a large field for scientific research. Even if is observed a large number of known plants, a small percentage has already been phytochemically investigated and only a fraction of them has already been assessed to determine its pharmacological potential. Even among traditional medicinal plants there is still a large percentage that has not been studied to confirm
}

their efficacy and safety in humans ${ }^{27}$.

In peptic ulcer this is also observed. In a study conducted by Mentz and Schenkel ${ }^{20}$, in which they assessed plants with popularly known effects to scientifically prove them, they observed that plants like Symphytum Officinale $L$. (Comfrey), besides having no proven efficacy it may be harmful because of their pyrrolizidine alkaloids, of proven hepatotoxic action. Another studied plant was Zantoxylon rhoifoliun Lan ("mamica-de-cadela"), popularly indicated for ulcers and healing, but its benefits have not been proved either. In addition, Maytenus ilicifolia Mart, commonly known in Brazil as "espinheira-santa", used for healing peptic ulcer, has not proven this effect in trials either.

Studied the effects of Peumus boldus ("boldo") and Baccharis genistelloides ("carqueja"), both commonly used to treat digestive problems and ulcers. The studies that proved various activities popularly attributed to these plants are associated with the isolate chemical compounds, such as, for example, flavonoids, antioxidants found both in boldo and carqueja leaves. However, the benefits of these teas in the cure of peptic ulcer have not been scientifically proven ${ }^{27}$.

The use of natural products in treatment of ulcer has been widely studied. However, most of the studies ${ }^{7}$ that have proven an anti-ulcer effect were conducted with animals, and therefore do not provide reliability for alternative treatments in the prevention of relapses or for treatment of peptic ulcer in humans.

\section{CONCLUSION}

A balanced diet is vital in the treatment of peptic ulcer, once food can prevent, treat or even alleviate the symptoms involving this pathology. However, there are few papers that innovate dietotherapy; so additional studies addressing more specifically the dietotherapy for treatment of peptic ulcer, a disease that affects a large part of the population, are necessary.

\section{REFERENCES}

1. Annibale B, Marignani M, Monarca B, Antonelli G, Marcheggiano A, Martino G, Mandelli F, Caprilli R, Delle Fave G. Iron deficiency anemia and Helicobacter pylori infection. International Journal of Antimicrobial Agents, 2000;16:515-519.

2. Arnold M, Barbul A. Nutrition and wound healing. Plast Reconstr Surg. 2006;117:42-58.

3. Banerjee S, Hawksby C, Miller S, Dahill S, Beattie AD, Mccoll KE. Effect of Helicobacter pylori and its eradication on gastric Juice ascorbic acid. Gut.1994;35:317-22.

4. Cats, A. Effect of frequent consumption of a Lactobacillus case containing milk drink in Helicobacter pylori-colonized subjects. Alimentary Pharmacolog yand Therapeutics.2003;17:429-435.

5. Cesar ACG, Silva AE, Tajara EH. Fatores genéticos e ambientais envolvidos na carciogênese gástrica. Arq Gastroenterol.2002; 39:253-259.

6. Cordell GA, Colvard MD. Some thoughts on the future of ethnopharmacology. J Ethnopharmacol. 2005;100:5-1.

7. Donatini RS, IshikawaT, Barros SBM, Bacchi EM. Atividades antiúlcera e antioxidante do extrato de folhas de Syzygium jambos (L.) Alston (Myrtaceae). Rev Brasileira de farmacognosia. 2009;19:89-94

8. Diener JRC. Calorimetria indireta. Rev Ass Med Brasil.1997;43:245-53

9. Elitsur $Y$, Yahav J. Helicobacter pylori infection in pediatrics. 2005;10:47-53.

10. Ferguson M, Cook A, Rimmasch H, Bender S, Voss A. Pressure ulcer management: the importance of nutrition. Medsurg Nurs.2000;9:163-75.

11. Ferri-De-Barros JE, Winter DH, César KG, Gavinier LCS, Alencar MJ, Maria CSF. Transtornos relacionados ao uso de álcool em 1901 pacientes atendidos no pronto socorro municipal de Taubaté no ano 2000: contribuição para educação sociocêntrica em neurologia. Arq. Neuro-Psiquiatr.2000;62:307-312. 
12. Filisetti-Cozzi TMCC, Lajolo FM. Fibra alimentar insolúvel, solúvel e total em alimentos brasileiros. Rev Farm Bioquím. 1991;27:83-99.

13. Institute of Medicine. DRIs - Dietary Reference Intakes: Applications in Dietary Planning. National Academy Press. Washington, D.C. 2003. [Acesso em 2012 out 30]. Disponível em: URL: http://www. nap.edu/

14. Lafortuna CL, Agosti F, Marinone PG, Marazzi N, Sartorio A. The relationship between body composition and muscle power output in men and women with obesity. J Endocrinol Invest. 2004;27:854-61.

15. Lionetti E, Miniello VL, Castellaneta SP, Magistá AM, De Canio A, Maurogiovanni G, Ierardi E, Cavallo L, Francavilla R. Lactobacillus reuteri therapy to reduce side-effects during anti-Helicobacter pylori treatment in children: a randomized placebo controlled trial. Aliment Pharmacol Ther. 2006;24:146-18.

16. Martins LC, Corvelo TCO, Oti HT, Barile KAS. Soroprevalência de anticorpos contra o antígeno CagA do Helicobacter pylori em pacientes com úlcera gástrica na região Norte do Brasil. Revista da Sociedade Brasileira de Medicina Tropical. 2002;35:307-310.

17. Maicá A, Scheweigert I. Avaliação Nutricional em pacientes graves Revista Brasileira Terapia Intensiva. 2008;20:286-295.

18. Marotta K, Floch MH. Diet and nutrition in ulcer diases. Med. Clin. North Am.1993;77:88-17.

19. Mattos L, Martins I. Consumo de fibras alimentares em população adulta. Rev Saúde Públic. 2000;34:50-55.

20. Mentz LA, Schekel EP. Plantas medicinais: a coerência e a confiabilidade das indicações terapêuticas. Caderno de farmácia. 1989;5:93-119.

21. Mitchell SL; Rockwood, K. The association between antiulcer medication and initiation of cobalamin replacement in older persons. J clin epidemiol. 2001;54:531-4.

22. Nieto Y. Protocolo terapéutico de la úlcera péptica. Medicine. 2012;11:179-82.

23. O'Neil-Cutting MA, Crosby WH. The effect of antacids on the absorption of simultaneously ingested iron. JAMA. 1986;255:1468-70.

24. Paulino E, Melo ACS, Cardoso MF, Schiavon LL, Narciso JL, Buzzolet FC. Demência e neuropatia periférica reversíveis com reposição parenteral de vitamina B 12. Rev Soc Bra Clin Med. 2008;6:123-124.

25. Prasad AS. Zinc: role in immunity, oxidative stress and chronic inflammation. Curr Opin Clin Nutr Metab Care. 2009;12:646-652.

26. Räihä I, Kemppainen H, Kaprio J, Koskenvuo M, Sourander L. Lifestyle, Stress, and Genes in Peptic Ulcer Disease: A Nationwide Twin Cohort Study. Internal Medicine. 1998;158:698-704.

27. Rates SMK. Plants as source of drugs. Toxicon. 2001;39:603-613.
28. Ravasco P, Camilo ME, Gouveia-Oliveira A, Adam S, Brum G. A critical approach to nutritional assessment in critically ill patients. Clinical Nutrition 2002;21:73-7.

29. Reis NT. Nutrição clínica: sistema digestório. 1 ed. Rio de Janeiro: Rubio; 2003.

30. Rosemberg J, Rosemberg AMA, Moraes MA. Nicotina: droga universal. São Paulo. Secretaria da Saúde. Centro de vigilância Epidemiológica. 2003.

31.Saul C, Teixeira CR; Julio C, Pereira-Lima JC, Torresini JRS. Redução da prevalência de úlcera duodenal: um estudo brasileiro (análise retrospectiva na última década: 1996-2005). Arq de gastroenterologia. 2007;44:320-324.

32. Sgouras DN, Panayotopoulou EG, Martinez-Gonzalez B, Petraki K, Michopoulos S, Mentis A. Lactobacillus johnsoniiLa1 attenuates Helicobacter pylori-associated gastritis and reduces levels of proinflammatory chemokines in C57BL/6 mice. Clinical and Diagnostic Laboratory Immunology. 2005;12:1378-1386.

33. Stefe C, Alves M, Ribeiro R. Probióticos, prebióticos e simbióticos - Artigo de revisão. Saúde e Ambiente. 2008;3:16-33.

34. Sung JJ, Tsoi KK, Ma TK, Yung MY, Lau JY, Chiu PW. Causes of mortality in patients with peptic ulcer bleeding: a prospective cohort study of 10,428 cases. Journal Gastroenterol. 2012;105:84-89.

35. Suerbaum S, Michetti P. Helicobacter pylori infection. N Engl J Med. 2002;347:117-586.

36. Toneto $\mathrm{M}$, Oliveira F, Lopes MH. Evolução histórica da úlcera péptica: da etiologia ao tratamento. Scientia Medica. 2011;21:23-30.

37. Vasiljevic T, Shah NP. Probiotics- From Metchnikoff bioactive. International Dairy Journal. 2008;18:714-728.

38. Wang KY, Li SN, Liu CS, Perng DS, Su YC, Wu DC, Jan CM, Lai $\mathrm{CH}$, Wang TN, Wang WM. Effects of ingesting Lactobacillus- and Bifidobacterium-containing yogurt in subjects with colonized Helicobacter pylori. Sep. 2004;80:737-41.

39. Yeho EJ, Ross ME, Shurteff AS, Williams WK, Patel D, Mahfouz R, Behn FG, Raimond, SA, Relling MV, Patel A, Cheng C, Campana D, wilkins D, Zhou X, Li J, Liu H, Pui CH, Evans We, Neave C, Wong $\mathrm{L}$, Downing JR. Classification, subtype discovery, and prediction of outcome in pediatric acute lymphoblastic leukemia by gene expression profiling. Cancer Cell. 2002;1:133-143.

40. Zojaji H, Talaie R, Mirsattari D, Haghazali M, Molaei M, Mohsenian $N$, Derakhshan F, Zali MR. The efficacy of Helicobacter pylori eradication regimen with and without vitamin $C$ supplementation. Digestive and Liver Disease. 2009;41:644-647. 